\title{
THE BLOOD GROUPS OF GASTRIC ULCER-CANCER
}

\author{
BY \\ W. H. BEASLEY \\ From the Department of Pathology, St. Woolos Hospital, Newport, Mon.
}

(RECEIVED FOR PUBLICATION DECEMBER 2, 1959)

\begin{abstract}
There was a statistically significant excess of Group A blood in a series of ulcer-cancers. It is concluded that an ulcer in a patient of Group $\mathbf{A}$ is more liable to become malignant than one in a patient of Group 0.
\end{abstract}

It has been shown by a number of authors that there is an excess of blood Group $A$ in carcinoma of the stomach and Group $\mathrm{O}$ in chronic gastric ulcer. Consequently, it has been postulated that Group A antigen possesses a carcinogenic effect and Group $\mathrm{O}$ a protective effect against cancer. If this is true then malignant change in a chronic gastric ulcer should occur more often in patients of Group A than of Group O. If not, then the group distribution in ulcer-cancer would be the same as in chronic gastric ulcer from which it originates.

However, whether or not malignancy ever develops in a chronic gastric ulcer has been debated for over a century. Some authors consider that the change never occurs and others that most cancers arise from chronic ulcers. This difference of opinion depends largely on the criteria adopted to decide whether or not there is evidence of a pre-existing gastric ulcer in the carcinoma.

The wide criteria of MacCarty and Broders (1914) led them to believe that 472 out of 684 cancers of the stomach possessed the characteristics of simple ulcer with carcinoma. Dible (1925) presented much more definite histological evidence of the existence of previous ulceration in a gastric cancer. From a study of chronic gastric ulcers, he listed three characteristics: (1) Muscular destruction ; (2) endarteritis or organizing thrombi; (3) extensive fibrosis. He qualified these to some extent by saying that carcinoma can give rise to endarteritis and that fibrous tissue may be due to a scirrhous carcinoma. The presence of a continuous band of muscle, in Dible's opinion, excluded a pre-existing ulcer. In 33 gastric carcinomata he found no evidence of preceding ulcer in 28 , and in the remaining five he was not certain histologically whether or not the ulcer had preceded the cancer, and he felt that the appearance might have been produced by the sclerosing character of the growth. Turning to clinical evidence, he noted that a long history had been obtained in only two cases (five years and 20 years respectively), and he thought it hardly admissible to adhere to a histological diagnosis in the face of contrary clinical evidence.

In the same year (1925), Cabot and Adie had decided, as the result of long experience and of a survey of the literature, that a history of previous ulceration was unreliable for judging the relationship between ulcer and cancer. They also quote Kocher, who claimed that he had personally examined the Mayo Clinic specimens and was convinced that much of what Wilson and MacCarty (1909) labelled as carcinomatous degeneration was atypical proliferation of epithelium or only epithelial changes in the progress of the ulcer and had nothing to do with carcinoma. In their assessment of ulcer-cancer, Cabot and Adie used criteria given them by W. S. Warthin, and these were induration or cicatricial fibrosis extending through the stomach wall, sclerosis of the blood vessels, and a scar, the greater part of which was free from cancer cells.

Newcomb in 1925 stated that in chronic ulcers the muscularis mucosae and muscularis lose their normal parallel relationship and, because of cicatricial contractions, fuse or approximate near the edge of the ulcer. He thought that this was proof of the previous existence of an ulcer.

A great deal of work, over many years, on this subject of the development of cancer in chronic gastric ulcer was carried out by Stewart. In 1926 he published his findings and agreed with the criteria laid down by Dible (1925). He thought that the complete destruction of the muscle coat of the greatest importance and stated that relics of the muscle coat persist in all early cancers and in many fairly advanced ones, but they are not 
seen in chronic gastric ulcer. In only very rare cases do secondary ulceration and sloughing of a carcinoma extend through a tumour and destroy all traces of the original muscularis. He added that dense cancer-cell-free fibrous tissue is not produced by carcinoma, and, whilst complete destruction of the fibrous floor by cancer is possible, it would more likely be seen only in very advanced malignant disease. He pointed out that cancer usually begins in a chronic ulcer in the edge and then spreads outwards from and arounci the ulcer, rather than into the floor. In several of his specimens he thought there was evidence that the malignant change had originated in the floor rather than in the edge of the ulcer. Endarteritis he considered as of little value in the absence of the other signs of chronic gastric ulcer, though it, was less common in primary gastric carcinoma. He noted the termination of the frayed ends of the muscularis in the walls of the ulcer, or at a later stage turning up into the floor near the margin, but did not describe it as approximation or fusion of the muscularis mucosae and muscularis.

In 1930, Newcomb again laid great stress on the histological sign of fusion and added that it was "the only certain criterion for the diagnosis of ulcer cancer," and that "it was suggested that fusion of the muscularis mucosae with the muscularis is as important a point in the diagnosis of ulcer-cancer as the finding of spirochaetes in syphilis."

Stewart (1931), in a further report, reiterated his criteria and again emphasized the presence of areas of fibrosis free from cancer cells. He stated that " no conclusive evidence is available, on the other hand, that peptic ulceration of a primary carcinoma is capable of producing a zone of cancer-cell-free fibrosis in the floor." In discussing the relationship of the muscularis mucosae and muscularis, he thought that if fusion were insisted upon a number of true cases of ulcer-cancer would be described as primary carcinoma. It was his opinion that fusion was evidence of healing and that carcinoma could undoubtedly develop in ulcers where there was no indication of healing.

In 1932, Newcomb gave an extensive review of the vast literature on this subject, demonstrating the wide diversity of views on the development of cancer in a chronic gastric ulcer. To establish evidence of chronic ulceration, he examined 161 chronic gastric ulcers, though he included five in which the muscularis had not been completely destroyed. His criteria were, largely, those of
Dible (1925) and Stewart (1926), but he stressed. the great importance of fusion or approximatio $\overrightarrow{\vec{F}^{3}}$ of the muscularis mucosae and muscularis, which he said was first described by Turnbull, adding that he found it in 159 of the 161 ulcers $(98.8 \%)$

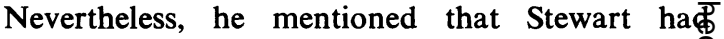
observed in uncomplicated gastric ulcers that the two muscle layers were widely separated. He summarized his opinion of fusion or approxima $\vec{e}$ tion by the statement that "this criterion is as valuable as the demonstration of tubercle bacilly in the diagnosis of tuberculosis."

Gömöri (1933) carried out a histological investi gation of carcinoma arising in gastric ulcers. Hi criteria agreed with those of Dible, Newcomb $b_{\omega}^{+}$ and Stewart, except that in his control series of chronic gastric ulcer, unlike Newcomb, he found fusion or approximation of the muscularis mucosae and muscular layer not in almost alk ulcers but in 56 out of $64(87 \%)$. He though that the fusion or approximation depended largely on the phase which happened to prevaig at the time of examination. In his report he quoted Borrman, who believed that it is rare fop carcinoma to develop in an ulcer; but Borrmant accepted only those lesions in which a small pare of the ulcer base was occupied by tumour and inf which the ulcer base was free from malignan? cells.

Ewing (1936) believed that gastric digestion and infection could reduce the original cancer to at narrow rim of malignant tissue lying beneath the overhanging edge of an ulcer, and went on tos state that islands of cancer cells in the edge of an? ulcer were no indication that the cancer cells were preceded by the ulcer.

In 1938, Klein, who investigated a large mixed series of gastrectomy and post-mortem specimens, reported on eight that appeared macroscopically to be ulcer-cancers. He thought that three of $=$. them could be instances of the development of $N$ carcinoma in a chronic gastric ulcer. His Cases $N$ 4 and 5, he agreed, looked to be typical chronic N peptic ulcer on one block, but further blocks showed infiltration of the base by carcinoma and this sign he regarded as against the diagnosis of ulcer-cancer. Of the remaining three, two he described as ulcerated cancers and one was $a^{+}$ benign peptic ulcer. He completely disagreed $\frac{0}{0}$ with Newcomb that close approximation or fusion $\frac{\mathbb{\mathbb { D }}}{\mathrm{O}}$ of muscle and muscularis mucosae was patho- $\frac{\rho}{\square}$ gnomonic of pre-existing chronic ulcer, and $\stackrel{\mathbb{Q}}{\varrho}$ believed that all signs of chronic peptic ulcer? would be produced in a malignant tumour by the 8 process of peptic digestion. 
Doubt concerning the development of cancer in chronic gastric ulcers was expressed by Palmer (1939) in whose opinion fibrosis, destroyed muscle, fusion or approximation of muscularis mucosae and muscle layer, and endarteritis were not pathognomonic of a pre-existing benign ulcer, and "any or all of them may be found with primary carcinoma." His Fig. 2 is described as a "cross-section through ulcerating carcinoma showing scar tissue, floor, and general architecture of benign ulcer." This picture is a $\times 6$ magnification and has the appearances of a chronic gastric ulcer, yet he states that it may be attributed to peptic digestion of carcinoma.

In a subsequent report with Humphreys, in 1944, he repeated his opinions, and these two authors stated that, as healing processes are so commonly seen in peptic ulceration, one should not be surprised to find similar healing in peptic ulceration occurring in tumour tissue. These illustrations and descriptions of Palmer and Humphreys (1944) were considered by Stewart (1953) to be by no means wholly convincing.

Mallory (1940) concluded that peptic ulceration of carcinoma in situ is usually interpreted as evidence of carcinoma arising in an ulcer.

In 1947, Stewart returned to the difficulty caused by superficial ulceration of a scirrhous cancer, but he pointed out that it did not resemble a chronic gastric ulcer and that in the scirrhous type the muscularis mucosae often persists. Some years later, in the Macewen Memorial Lecture of 1953, Stewart, in discussing this same diagnostic point, said that in an active ulcer, oedema, inflammatory cells, and fibrosis could so widen the submucosa that separation of the muscularis mucosae and muscularis would follow rather than approximation. On the same occasion he mentioned subserosal fibrosis with islets of fat, and stated that this "is not met with, in my experience, in primary carcinoma, however deeply ulcerated."

Fusion of the muscularis mucosae and muscularis was referred to by Morgan and Lee (1954), who considered it a valuable sign, but thought that its absence did not exclude the diagnosis of ulcer-cancer. They, too, noted that fusion could be destroyed by tumour.

Figures concerning the number of carcinomata that arise in gastric ulcers have varied widely since this subject was first discussed in the middle of the nineteenth century. In his article in 1932, Newcomb listed 102 reports on this subject published during the period 1845-1925. He quoted the opinion of Rokitansky (1842), who said that it sometimes occurred with simple ulcer and that it might arise from the ulcer; Zenker (1882) that most cases of gastric carcinoma arise in a pre-existing ulcer; Duplant (1898) that the grafting of carcinoma on an ulcer is impossible. In half of these 102 reports quoted by Newcomb, the authors claimed that not more than $10 \%$ arose from gastric ulcers, while 15 gave a figure greater than $50 \%$. However, in the opinion of the majority ( 74 reports) $20 \%$ of carcinomata showed evidence of previous gastric ulceration, and, from the numbers and percentages given, Newcomb was able to calculate that $17.5 \%$ was an average.

Table I shows the figures for ulcer-cancers quoted by some of the papers published since 1925.

TABLE I

PERCENTAGE OF ULCER-CANCERS IN PREVIOUS SERIES

\begin{tabular}{|c|c|c|c|c|}
\hline & $\begin{array}{l}\text { No. of } \\
\text { Gastric } \\
\text { Cancers }\end{array}$ & $\begin{array}{l}\text { No. of } \\
\text { Ulcer- } \\
\text { cancers }\end{array}$ & $\begin{array}{l}\% \text { of } \\
\text { Uicer- } \\
\text { cancers }\end{array}$ & $\begin{array}{l}\text { Methods } \\
\text { of } \\
\text { Diagnosis }\end{array}$ \\
\hline Dible (1925) & 33 & 2 & 6 & $\begin{array}{l}\text { Histological } \\
\text { and clinical }\end{array}$ \\
\hline 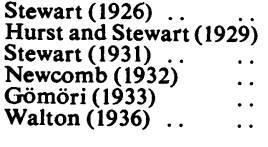 & $\begin{array}{r}97 \\
70 \\
109 \\
46 \\
26 \\
461\end{array}$ & $\begin{array}{r}17 \\
11 \\
17 \\
6 \\
6 \\
44\end{array}$ & $\begin{array}{l}17 \cdot 5 \\
15 \cdot 7 \\
15 \cdot 6 \\
13 \\
23 \\
9 \cdot 5\end{array}$ & $\begin{array}{c}\text { Histological } \\
\text {," } \\
\text { ", } \\
\text { Histological }\end{array}$ \\
\hline $\begin{array}{l}\text { Finsterer (1939) } \\
\text { Stewart (1947) .. } \\
\text { Grimes and Bell (1950) . . } \\
\text { Swynnerton and }\end{array}$ & $\begin{array}{l}673 \\
281 \\
171\end{array}$ & $\begin{array}{l}96 \\
51 \\
24\end{array}$ & $\begin{array}{l}14 \cdot 2 \\
18 \cdot 0 \\
14 \cdot 0\end{array}$ & $\begin{array}{c}\text { and clinical } \\
\text { Histological } \\
\text { Clinical } \\
\text {," }\end{array}$ \\
\hline \begin{tabular}{l}
\multicolumn{1}{c}{ Truelove (1951)* } \\
Ekström (1952). \\
Stewart (1953) $\ldots$ \\
Morgan and Lee (1954) \\
Gilmour (1958)
\end{tabular} & $\begin{array}{l}375 \\
138 \\
581 \\
104 \\
168\end{array}$ & $\begin{array}{r}24 \\
14 \\
103 \\
2\end{array}$ & $\begin{array}{r}6 \cdot 5 \\
10 \cdot 2 \\
17 \cdot 7 \\
2 \\
13 \cdot 7\end{array}$ & $\begin{array}{c}\text { Histological } \\
\text {," } \\
, " \\
\text { ", }\end{array}$ \\
\hline
\end{tabular}

*Expressed less certainty about this in 1952.

Dible (1925) had invoked the history of dyspepsia to help in the diagnosis of ulcer-cancer and had excluded this diagnosis because of a short history in three patients. In their book Gastric and Duodenal Ulcer (1929) Hurst and Stewart showed that a chronic gastric ulcer could exist without causing serious symptoms, and that a short history did not necessarily preclude the possibility of ulcer. Newcomb (1932) felt that it was wrong to assume that a malignant change arose in a gastric ulcer merely because it had a long history.

Doubts concerning malignant change taking place in chronic gastric ulcers have been expressed. Zachary Cope (1925) said that " there seemed little evidence that a simple ulcer ever ended in carcinoma." There was no doubt in the mind of Schindler (1941), who did not believe that gastric ulcers ever became malignant, and added that as $3-4 \%$ of all adults die from carcinoma of the stomach it was to be expected that the same 


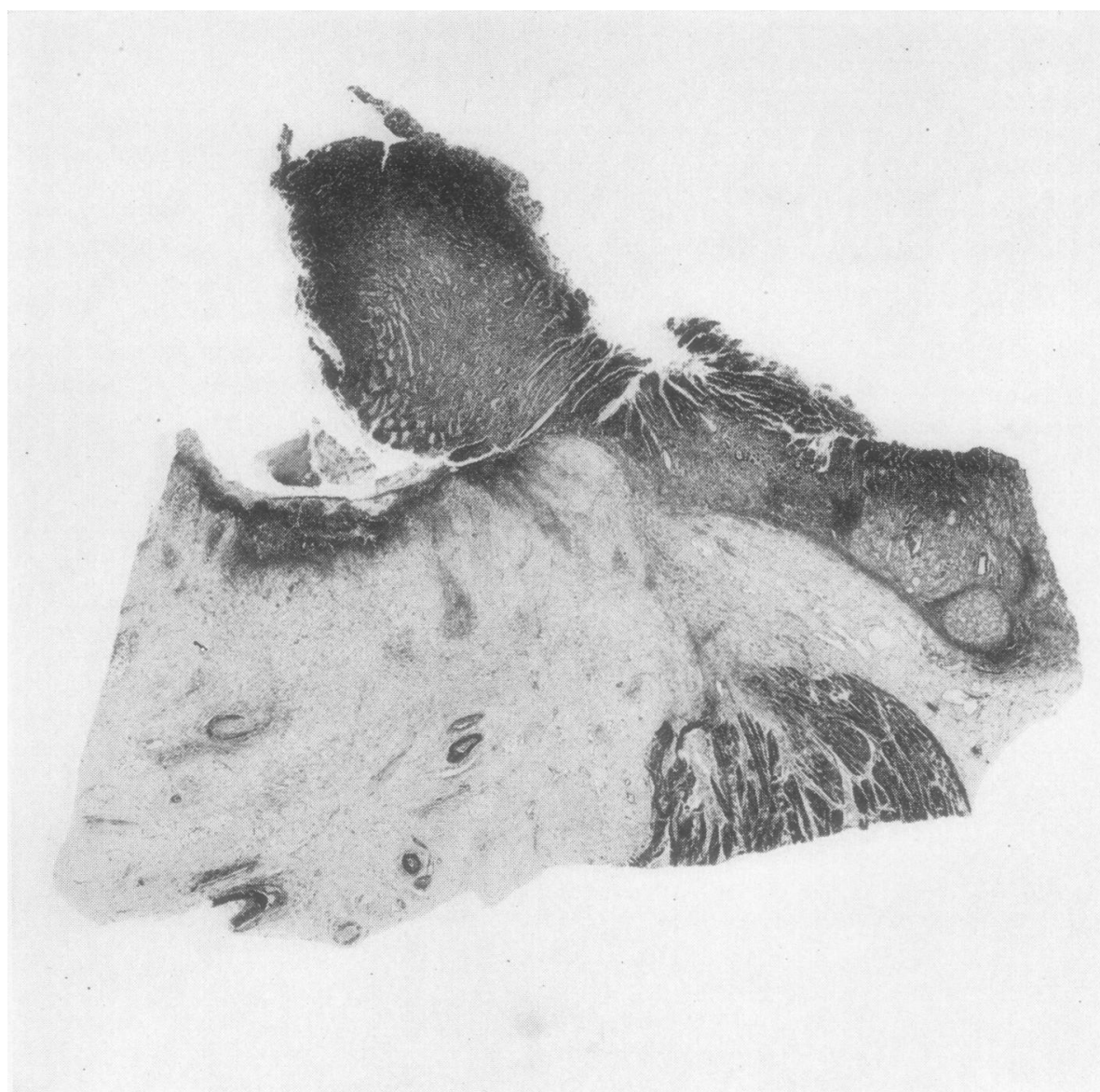

FIG. 1.-Fusion of muscularis and muscularis mucosae in a chronic gastric ulcer $\left(\times 77^{\circ}\right)$.

percentage of all ulcer patients would develop a carcinoma also. Palmer and Humphreys (1944) doubted if a gastric ulcer ever developed malignant change. In 1951 Swynnerton and Truelove wrote that they had found 24 ulcer-cancers histologically proved, but in the following year they expressed less certainty about them. Sir Heneage Ogilvie in 1952 said, "I myself have never seen an undoubtedly innocent peptic ulcer change to a cancer," and further, "I believe it is the cancer that caused the ulcer, rather than the ulcer that caused the cancer." His explanation was that they were scirrhous cancers which had been attacked by the gastric juice and then undergone healing in those parts where all the malignant cells had been digested away. However, he admitted that it was not possible to distinguish between simple and malignant ulcers radiologically and clinically.
I think it would be agreed that only a histo logical examination can show if an ulcer preceded? a carcinoma and, even then, it is not always possible to be certain, so figures based or. investigations other than histological are even more liable to error. Then again, there are many stomach cancers that are never resected because of the inoperability of the disease, and it is not unlikely that some of those might have originated in chronic gastric ulcers. At the same time figures of malignant change in ulcers derived from the percentage of ulcer-cancers of all resected? gastric ulcers are equally erroneous, for to beo true the number of ulcer-cancers should be relate $\bar{\phi}$ to all gastric ulcers, many of which do not come to operation.

\section{Methods}

Ulcer-cancers.-This series of ulcer-cancers was? obtained by examining the routine histological section? 


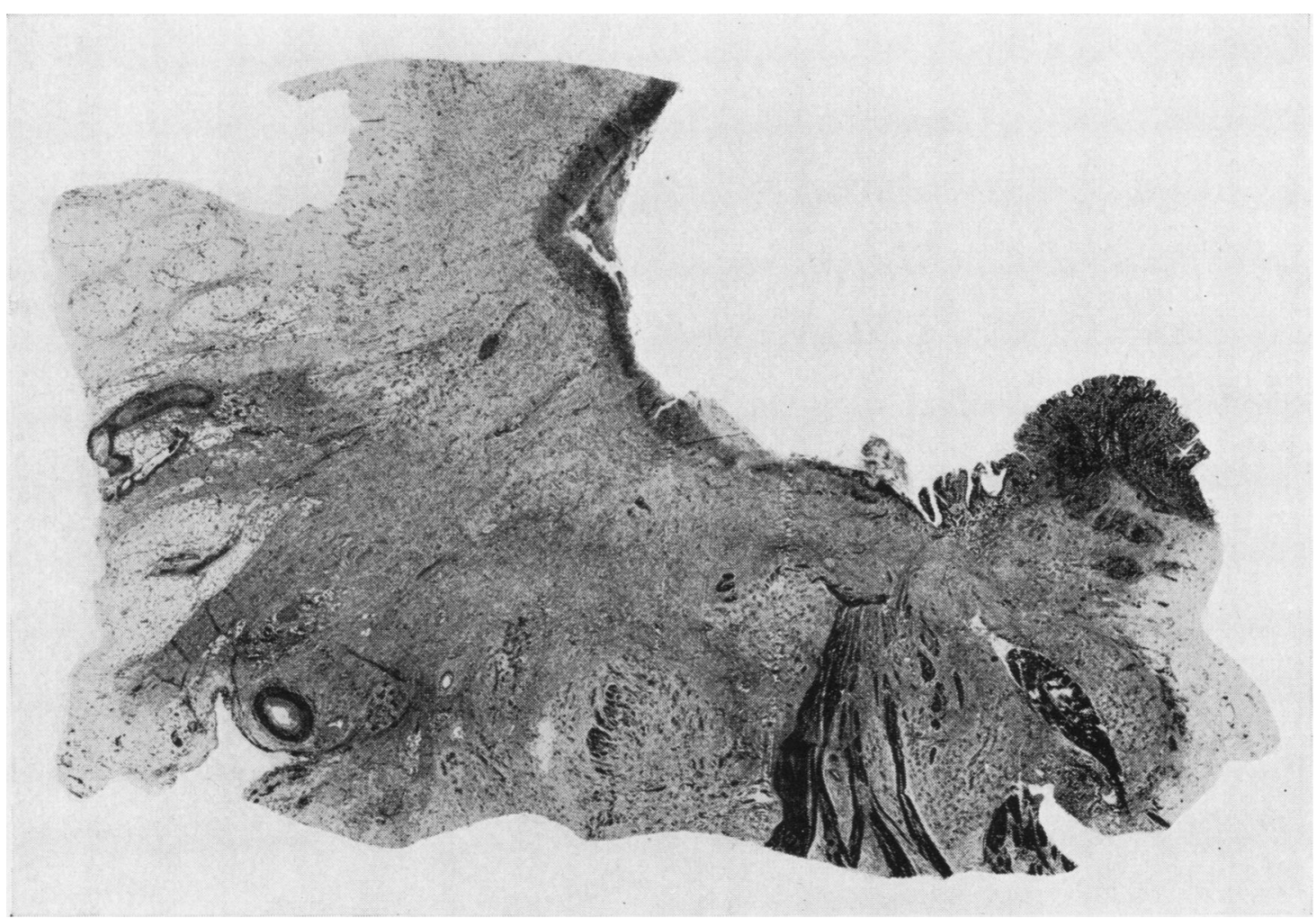

FIG. 2.-Approximation of muscularis and muscularis mucosae in an ulcer-cancer $(\times 7)$.

of 708 gastric cancers removed by gastrectomy or at necropsy. The diagnosis was made without knowledge of clinical facts or blood groups.

As has already been shown, many reports have been published that set out criteria for the diagnosis of ulcer-cancer. However, I decided to re-examine these criteria, in the light of information obtained from routine histological sections from 88 gastric ulcers removed surgically. All possessed the feature of a complete breach in the main muscle coat and this breach was filled by fibrous and granulation tissue.

The relationship of the muscularis mucosae to the main muscular coat was observed. The mingling of the muscle fibres of these was called fusion (Fig. 1). When the muscle fibres of both approached each other but did not fuse, this condition was called approximation (Fig. 2). Then there were some cases where the muscularis mucosae and muscularis still remained parallel, i.e., there was neither fusion nor approximation (Fig. 3).

Of the 88 ulcers in this series neither fusion nor approximation was found in 19, but fusion or approximation was observed in 69 , although in several ulcers extension of the ulceration appeared to have obliterated evidence of fusion or approximation (Fig. 5). This gives a percentage of 78.4 compared with Newcomb's 98.8 and Gömöri's 87.
Chronic inflammatory changes often lead to the development of obliterative changes in the vessels in the floor of an ulcer. All reports that mention this feature point out, however, that it has little diagnostic value, but may have some usefulness as corroborative evidence (Fig. 6). More than a slight degree of endarteritis was found in 51 of these 88 ulcers $(58 \%)$ and there was no endarteritis in 12 of them. Newcomb found it in $72 \%$ of his series. In primary carcinoma the comparable findings were that $12 \%$ of 649 had more than a slight degree of endarteritis and $73.1 \%$ had none. My results confirm its unreliability as a sign of previous chronic gastric ulceration.

One of the pitfalls in the diagnosis of ulcer-cancer is the misconstruing of irregularities in the size and shape of cells and nuclei and of mitoses in the glands in the edge of the ulcer as evidence of carcinoma. This may account for the fact that some authors have reported a high incidence of malignant changes in chronic gastric ulcer. For the purposes of this investigation, it was decided to accept only definite cases of cancer and in no instance was a diagnosis made on such cellular irregularities.

Difficulties also arose when there was superficial ulceration of a scirrhous carcinoma, and, in contrast, when masses of tumour cells obliterated the normal anatomy, and made it impossible to find any smooth 


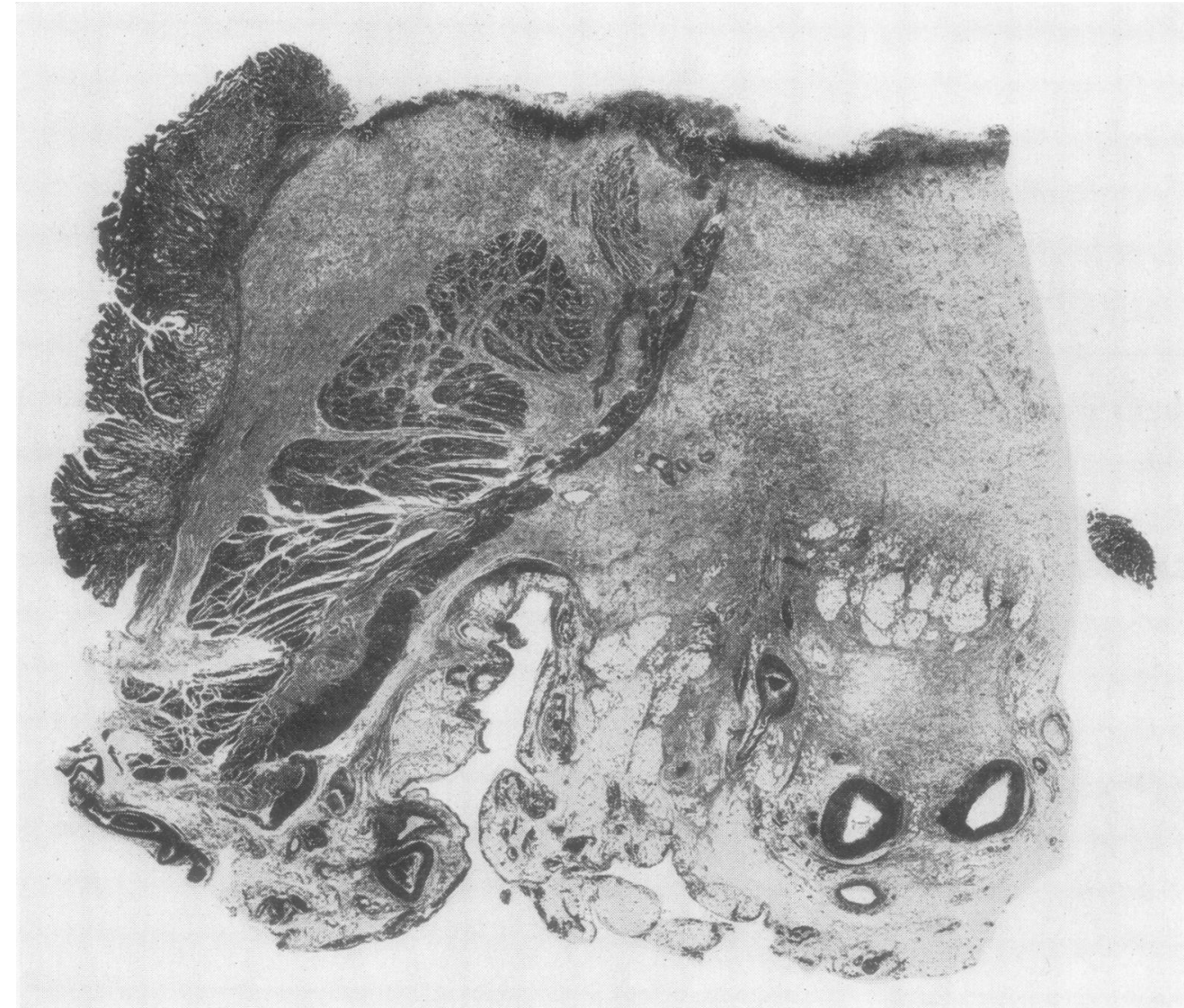

FIG. 3.-Neither fusion nor approximation in an ulcer-cancer $\left(\times 7 \frac{1}{3}\right)$.

muscle. Then, however, the absence of areas of cancer-cell-free fibrosis and scar tissue placed the tumour in the primary group.

Scar tissue containing no cancer cells has been emphasized as a diagnostic feature. Spilsbury (1922) argued that cancer cells were unlikely to invade sclerotic and poorly vascular tissue, but are much more likely to spread centrifugally into the softer and highly vascular tissues around the ulcer. I think this is rather too rigid a criterion, for the scar tissue in the floor of chronic gastric ulcers shows much variation in vascularity. Some show many vessels and others a few, and some have a more cellular fibrous tissue than others. Newcomb (1932) observed these differences. Thus it would be logical to expect that cancer cells could invade the floor of an ulcer along the course of blood vessels in those cases where the floor is vascular, and, if the invasion were great enough, occupy a large area of the floor of the ulcer. In several sections it was noticeable that cancer cells were numerous near the peritoneal surface and extensions upwards into the scar tissue could be observed along the courses of vessels and nerves.
The criteria I looked for to indicate previous chronic gastric ulceration in a carcinoma were $\mathscr{Q}$ (1) A complete breach in the muscle coat; (2) the occupation of this breach by fibrous and granulation tissue ; (3) fusion and approximation of the muscularis mucosae and muscularis ; (4) areas of cancer-cell-free
fibrosis.

Chronic Gastric Ulcers.-The case records from $\cong$ number of hospitals were examined and from thespu 690 cases of chronic gastric ulcer, which had been diagnosed histologically, were obtained together with
their blood groups.

Carcinoma of the Stomach.-I was able to find fronf the clinical records of a number of hospitals th blood groups of most of the cases of carcinoma of the stomach that I examined in order to find ulcer cancers.

\section{Results}

In a total of 708 carcinomata of the stomach 59 ulcer-cancers were found. The blood groupई were available in 57. 


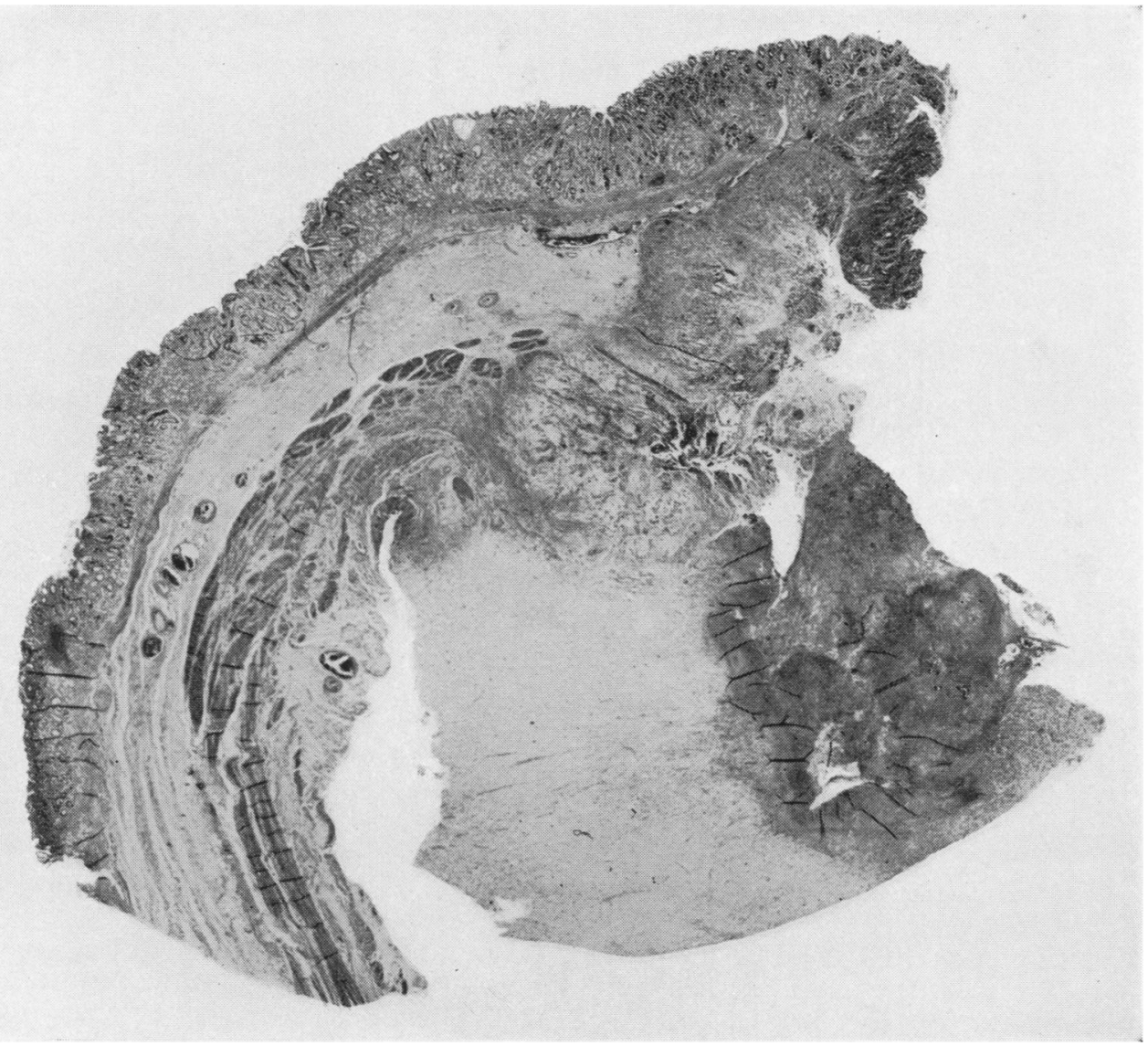

FIG. 4.-Destruction of fusion or approximation by tumour in an ulcer-cancer $(\times 7)$.

The essential criterion was that there should be a gap in the muscle coat and this gap occupied by scar tissue. This was observed in all cases.

Cancer-cell-free fibrosis was noted in all, except that in four it was not as marked as in the others.

Fusion or approximation was observed in 32 ulcers and in 18 ulcers neither feature was observed. In four it appeared that neoplastic tissue had destroyed fusion or approximation (Fig. 4) and in one that it had been destroyed by ulceration.

In four cases the only sections available were of the floor of the ulcer and did not show the edge of the ulcer.

Endarteritis of more than a slight degree was seen in 40 cases, a slight degree in 13 , and none in six.

Though this investigation was not planned to find the percentage of cancers that are derived from ulcers, the overall percentage of ulcercancer compared with the total gastric cancer is
$8.3 \%$, which is less than the figures quoted by Stewart $(1926 ; 1931 ; 1947 ; 1955)$, Newcomb (1932), Gömöri (1933), and Walton (1936), but is a little higher than that of Dible (1925) whose figures were considered by Willis (1953) to be nearer the truth.

It is clear that there is an excess of Group A in the ulcer-cancer, for there are proportionately almost as many Group A bloods in ulcer-cancer as there are Group $\mathrm{O}$ in chronic gastric ulcer (Table II).

\section{TABLE II}

TABLE OF BLOOD GROUPS OF ULCER-CANCER AND OF CHRONIC GASTRIC ULCER

\begin{tabular}{|c|c|c|c|c|c|}
\hline & 0 & $\mathbf{A}$ & B & $\mathbf{A B}$ & Total \\
\hline $\begin{array}{l}\text { Ulcer-cancers } \\
\text { Histologically } \\
\text { proved gastric } \\
\text { ulcers }\end{array}$ & $\begin{array}{c}21 \\
(36.8 \%) \\
372 \% \\
(53.92 \%)\end{array}$ & $\begin{array}{c}29 \\
(50 \cdot 9 \%) \\
254 \% \\
(36.81 \%)\end{array}$ & $\begin{array}{c}7 \\
(12 \cdot 3 \%) \\
49 \\
(8 \cdot 10 \%)\end{array}$ & $\begin{array}{c}15 \\
(2.17 \%)\end{array}$ & $\begin{array}{c}57 \\
690\end{array}$ \\
\hline
\end{tabular}




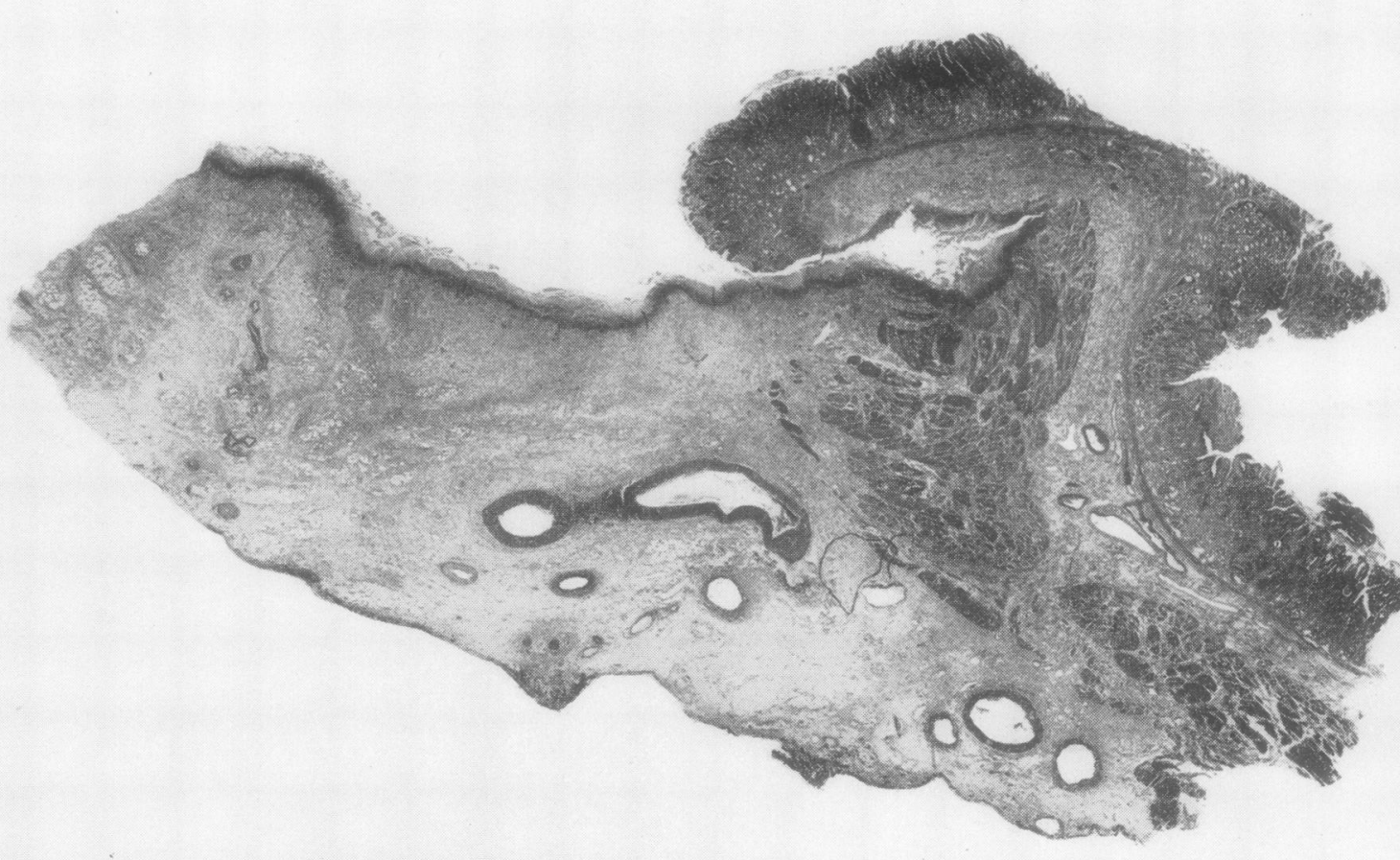

FIG. 5.-Destruction of fusion or approximation by ulceration in a chronic gastric ulcer $(\times 7)$.

Of the ulcer-cancers $50.9 \%$ and of the gastric ulcers $36.8 \%$ were Group A, a significant difference of $14.1 \pm 6.7$.

\section{Discussion}

This work has shown that there is a significant excess of blood Group A amongst cases of ulcercancer when compared with cases of benign chronic gastric ulcers. Whether or not a chronic gastric ulcer can become malignant is strongly disputed, and many believe that all the features of a chronic gastric ulcer can be reproduced by a cancer: that the fibrosis, muscle gap, fusion and approximation of muscularis mucosae and muscularis could be attributed to peptic digestion of a malignant tumour. It is believed that the evidence presented in this series supports the view that malignant change occurs in a chronic gastric ulcer.

In four of this series of ulcer-cancers, there were histories of indigestion for 20 years, 20, 30, and 40 years respectively. If it is assumed that ulcercancers are cancers from the outset, then it follows that peptic digestion had been taking place for those long periods of time and that the cancer had remained apparently localized to the stomach for the greater part of that time. This is difficult to accept. In cancer, peptic digestion causes a superficial necrosis and inflammatory response and it appears unlikely that the destroyed tumour is replaced by scar tissue. Similarly the invasion and destruction of the muscularis by neoplastic tissue are not followed by the formation of fibrous 3 and granulation tissue.

It has been suggested that scar tissue is impermeable to cancer cells and that therefore the presence of cancer cells in the scar tissue supports $>$ the diagnosis of primary cancer of the scirrhous type. The bases of chronic gastric ulcers vary widely in their cellularity and vascularity, and cancer with its known characteristic of spreading 0 along perivascular lymphatics could extend into a scar along the course of blood vessels and, if the scar were very vascular, could produce exten-e sive tumour infiltration in the base of an ulcer.

Short histories of a gastric disorder are not $\stackrel{\mathcal{P}}{?}$ exceptional in chronic gastric ulcer, and most $\underset{-}{-}$ pathologists, at some time or another, must have $\frac{\vec{\Phi}}{\mathbb{D}}$ found, unexpectedly, a chronic gastric ulcer at a $\stackrel{\mathbb{P}}{\stackrel{P}{ }}$ necropsy. Thus, too much emphasis ought not $\stackrel{\mathbb{Q}}{\mathscr{Q}}$ to be placed on a long duration of clinicalo symptoms in the histological diagnosis of an 0 ulcer-cancer. 


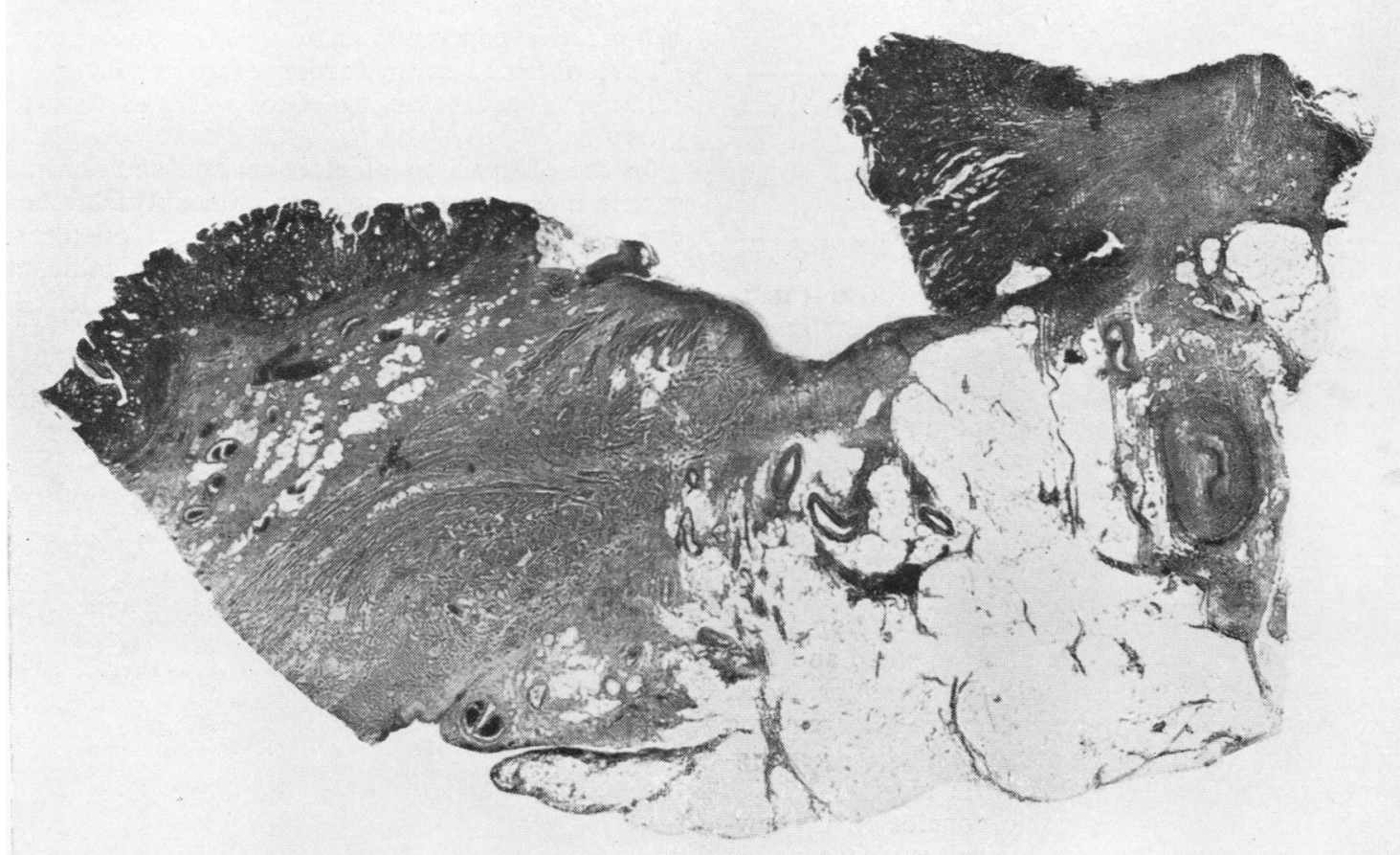

FIG. 6.-Endarteritis and fat islets in a chronic gastric ulcer $\left(\times 7 \frac{1}{2}\right)$.

Therefore, if the histological appearances of the ulcer-cancers with the longest histories can be closely matched with those of others with shorter histories, then I have concluded that in all of them the lesion was originally the same, i.e., a chronic gastric ulcer.

In the margin of many chronic ulcers, and not only in those in the stomach, there is often some degree of irregularity of the epithelium. The cells show a variation in size and shape, stain more deeply and exhibit increased mitotic figures, and these features can give rise to difficulty in diagnosis. It is believed that cancer develops from these atypical foci, eventually spreading through the muscularis mucosa into the submucosa. In one case, invasion of the muscularis mucosa had only just begun, but an adjacent -lymph node contained a small metastasis, thus making a convincing histological diagnosis. One patient, not included in this series, had had a partial gastrectomy for chronic gastric ulcer, but four years later he was found to have carcinoma of the gastric stump. Re-examination showed definite cellular irregularity at the edge of the ulcer but no invasion of the muscularis mucosae. This may be dismissed as a coincidence, but
Helsingen and Hillestad (1956) pointed out that after partial gastrectomy for chronic gastric ulcer there was a risk of developing cancers in the gastric remnant three times greater than after partial gastrectomy for duodenal ulcer. They gave no pathological details, but knowing that duodenal ulcers seldom, if ever, become malignant it perhaps can be assumed that malignant changes must have occurred in the original gastric ulcer, but that they were not apparent to the surgeon or pathologist at the time.

It is concluded, therefore, that the histological evidence supports the belief that malignant change can occur in a chronic gastric ulcer and that ulcers in patients of blood Group A are more likely to develop cancer. This conclusion receives some support from animal experiments. Willis (1953) quotes the work of Deelman (1924), who found that wounds of a tarred area of skin localized and hastened tumour formation. Thus it would appear reasonable that, when in a stomach, already predisposed to malignant change by blood Group A, an ulcer develops, that ulcer becomes the precursor of a carcinoma.

There is, however, another possible interpretation of the excess of Group $A$ in ulcer-cancer. 
TABLE III

BLOOD GROUPS OF ULCER'-CANCER AND PRIMARY GASTRIC CANCER

\begin{tabular}{|c|c|c|c|c|c|}
\hline & 0 & $\mathbf{A}$ & B & $\mathbf{A B}$ & Total \\
\hline $\begin{array}{l}\text { Ulcer-cancer } \\
\text { Primary cancer }\end{array}$ & $\begin{array}{c}21 \\
(36.8 \% \\
228\end{array}$ & $\begin{array}{c}29 \\
(50.9 \%) \\
236) \\
(55.560)\end{array}$ & $\begin{array}{c}7 \\
(12 \cdot 3 \%) \\
38\end{array}$ & $\frac{-}{16}$ & 518 \\
\hline
\end{tabular}

When the ABO blood groups of the ulcer-cancer series are compared with those of primary gastric carcinoma (Table III) it can be seen that there are no great differences in the group distribution, and that Group $A$ is predominant in both. The percentage of Group A in the ulcer-cancers was 50.9 and in primary cancer 45.6, giving an insignificant difference of $5.3 \pm 7.0$. This shows that there is statistically no difference between the ABO group in the ulcer-cancer and primary cancer groups. It perhaps can then be concluded that both diseases are one and the same and that ulcer-cancer is, in spite of histological evidence, just another manifestation of primary carcinoma of the stomach and is not an instance of malignant change in a chronic gastric ulcer.

This apparently reasonable conclusion is, however, contrary to the histological evidence which demonstrates quite convincingly that malignant changes do occur in a chronic gastric ulcer and therefore the possession of Group A blood rather than Group $O$ predisposes that ulcer to the development of cancer.

I wish to thank Professor J. Gough, Dr. G. S. Andrews, Dr. N. Brown, Dr. J. N. Dearnaley, Dr. J. Fine, Dr. D. McKinnon, Dr. T. Parry, and Dr. R. Sandry for allowing me to use their histological material.

My special thanks are due to Dr. G. S. Andrews for his advice on the preparation of this paper.

\section{Addendum}

Since this paper was submitted for publication, I have obtained seven further examples of ulcercancer. Three belong to Group $\mathrm{O}$ and four to group A.

In the comparison of ulcer-cancers and chronic gastric ulcers there is now a significant difference is of $14.75 \pm 6.3$, and in the comparison of ulcercancer and primary cancers there is an insignificant difference of $6.0 \pm 6.6$.

\section{REFERENCES}

Cabot, H., and Adie, G. C. (1925). Ann. Surg., 82, 86.

Cope, V. Zachary (1925). Lancet, 2, 1022.

Deelman, H. T. (1924). Quoted by R. A. Willis (1953)

Dible, J. H. (1925). Brit.J. Surg., 12, 666.

Duplant F (1898) “De la prttendue transformation de l'ulcer " rond en cancer," Th.se de Lyon. Quoted by Newcomb, W. D. $\vec{G}$

(1932). (1952). Acta chir. scand., 102, 387.
Ekström, T.

Ewing, J. (1936). Amer. J. Surg., 31, 204.

Finsterer, H. (1939). Proc. roy. Soc. Med., 32, 183.

Gilmour, J. (1958). Brit. med. J., 1, 745.

Gömöri, G. (1933). Surg. Gynec. Obstet., 57, 439

Grimes, O. F., and Bell, H. G. (1950). Ibid., 80, 359.

Helsingen, N., and Hillestad, L. (1956). Ann. Surg., 143, 173. Helsingen, N., and Hilestad, L. (1956). Ann. Surg., 143, 173.
Hurst, A. F., and Stewart, M. J. (1929). Gastric and Duodenal Ulcer.
Oxford University Press, London.

Klein, S. H. (1938). Arch. Surg. (Chicago), 37, 155.

Mallory, T. B. (1940). Arch. Path. (Chicago), 30, 348.

MacCarty, W. C., and Broders, A. C. (1914). Arch intern. Med. $13,208$.

Morgan, A. D., and Lee, E. S. (1954). Brit. J. Surg., 41, 595.

Newcomb, W. D. (1925). Lancet, 2, 1022. (1930). Proc. roy. Soc. Med., 23, 1251 (1932). Brit. J. Surg., 20, 279.

Ogilvie, H. (1952). Brit. med. J., 2, 299.

Palmer, W. L. (1939). Ann. intern. Med., 13, 317.

and Humphreys, E. M. (1944). Gastroenterology, 3, 257.

Rokitansky, C. von (1842). Handbuch der speziellen, pathologischen Anatomie, 1842. Quoted by Newcomb, W. D. (1932).

Schindler, R. (1941). J. nat. Cancer Inst., 1, 451 .

Spilsbury, B. H. (1922). Proc. roy. Soc. Med., 15, Section of Medicine, 25.

Stewart, M. J. (1926). J. Path. Bact., 29, 321.

(1931). Lancet, 2, 617.

(1947). Brit. J. Radiol., 20, 505

(1953). Macewen Memorial Lecture. Ulcer-Cancer of the Stomach. Jackson, Glasgow, 1955.

Swynnerton, B. F., and Truelove, S. C. (1951). Brit. med. J., 2, 1243. (1952). Ibid., 1, 287.

Walton, J. (1936). Lancet, 1, 1101

Willis, R. A. (1953). Pathology of Tumours, 2nd ed. Butterworth, London.

Wilson and MacCarty, W. C. (1909). Quoted by Cabot, H., and Adie, 의 G. C. (1925).

Zenker (1882). Quoted by Newcomb, W. D. (1932). 